\title{
Wetland nutrient retention and multitemporal growth - Case study of Riacho Fundo's Wetland
}

\author{
Retenção de nutrientes e crescimento multitemporal de wetland - \\ Estudo de caso da Wetland do Riacho Fundo
}

Rodrigo Zolini Dias ${ }^{1}$ and Gustavo Macedo de Mello Baptista ${ }^{1}$
'Instituto de Geociências, Universidade de Brasília - UNB, Pavilhão Multiuso I, Bloco A, CP 04410, CEP 70910-900, Brasília, DF, Brazil
e-mail: rodrigozolini@gmail.com; gmbaptista@unb.br

\begin{abstract}
Aim: The aim of this research was to evaluate the nutrient retention of Riacho Fundo's wetland in controlling Lake Paranoá (Brasília, Brazil) eutrophication analyzing its ability to retain nitrogen and phosphorus. Furthermore, the article aimed at verifying the multitemporal growth rate of Riacho Fundo's wetland. Methods: Five sampling points were distributed along the wetland, from its beginning to its outflow into Lake Paranoá. Twenty-five field campaigns during periods of drought and rain from November 2011 to October 2012 with intervals of fifteen days were accomplished. The parameters total nitrogen and total phosphorus were analyzed and for comparison between the sampling points a non-parametric statistical analysis was performed and the efficiency of retention of these parameters between input and outputs of the wetland was calculated. For the analysis of multitemporal pace of growth in the area of wetland, water area and was estimated by processed satellite images of the years 1973, 1985, 1995, 2005 and 2011. Results: The general behavior of the analyzed nutrients was decay between the entry point and exit point of showing an overall average retention of nitrogen $36.66 \%$ and $33.95 \%$ overall average total phosphorus. By image processing was possible to estimate that the surface of the lake was lost $0.5273 \mathrm{~km}^{2}$ or $84.07 \%$ of the initial area in the range of 38 years. Conclusion: Despite having lost water area, Lake Paranoá gained a natural filter that retains nutrients that could be being invested in it and so can cause eutrophication of its waters. Thus, the wetland provides an ecological service of water treatment and preservation of aquatic and terrestrial Lake Paranoá life and the wetland should be considered as an importanttheme in Lake Paranoá management.
\end{abstract}

Keywords: wetland; retention; nitrogen; phosphorus; eutrophication.

Resumo: Objetivo: O objetivo desta pesquisa foi avaliar o papel da wetland do Riacho Fundo no controle da eutrofização do Lago Paranoá (Brasília, Brasil) analizando sua capacidade de retenção de nitrogênio e fósforo. Também, o artigo visou verificar o ritmo multitemporal de crescimento da wetland. Métodos: Cinco pontos de amostragem foram distribuidos ao longo da wetland, partindo de seu início até o deságue no Lago Paranoá. Foram realizadas vinte e cinco campanhas de campo durante os períodos de seca e chuva de novembro de 2011 a outubro de 2012 com intervalos de quinze dias. Foram analisados os parâmetros nitrogênio total e fósforo total e para comparação entre os pontos amostrados foi realizada uma análise estatística não paramétrica e calculada a eficiência de retenção desses parâmetros entre entrada e saídas da wetland. A análise do ritmo de crescimento da área de lâmina d'água da wetland foi estimada por meio de imagens de satélite processadas dos anos 1973, 1985, 1995, 2005 e 2011. Resultados: O comportamento geral dos nutrientes analisados foi de decaimento entre o ponto de entrada e o ponto de saída mostrando uma retençáo média geral de 36,66\% do nitrogênio e de 33,95\% em média geral do fósforo total. Pelo processamento das imagens foi possível estimar que a superfície do lago perdida foi de $0,5273 \mathrm{~km}^{2}$ ou $84,07 \%$ da área inicial no intervalo de 38 anos. Conclusão: Apesar de ter perdido em área de lâmina d'água, o Lago Paranoá ganhou um filtro natural que retém nutrientes que poderiam estar sendo nele aportados podendo, assim, causar a eutrofização de suas águas. Sendo assim, a wetland presta um serviço ecológico de tratamento de água e de preservação da vida aquática e terrestre do Lago Paranoá e deve ser considerada sua importância em seu manejo.

Palavras-chave: wetland; retenção; nitrogênio; fósforo; eutrofização. 


\section{Introduction}

Natural wetlands functions as regulators of water flood, stopping the storms waters(reducing flood peaks), protecting lakes borders and shore areas of erosive action caused by waves and storm effects, and promotes an improvement on water quality by retaining or transforming excess nutrients, heavy metals and suspended solids. Besides the function of protecting the environment, wetland provides components as nesting sites, protection and habitats for wildlife (Welsch et al., 1995).

According to Valko (2006), wetlands in urban regions are important parts of the landscape and important system components that control the levels of nutrients and regulation of biogeochemical cycles, and thus maintaining the local biodiversity.

Wetlands lying within the boundaries of cities, towns, and non-agricultural areas adjacent to the urban region, including those wetlands located within the region of satellite towns around centre cities can be named Urban wetlands. Wetlands structure an important ecological infrastructure of urban areas and supply varied ecological and social services in urban ecoenvironments. It is now widely recognized that the sustainability of urban development depends on the provision and maintenance of forward looking municipal and ecological infrastructures (Weber \& Puissant, 2003; Xu et al., 2009).

Wetlands have its impact on the water quantity and quality. The removal of wetlands to develop agricultural activities, or construction of infrastructure has high ecological, economic and social costs. The conservation of natural wetlands is an important measure to control nutrients, recycle pollutants and heavy metals. This recyclability and high biodiversity of wetlands led to the organization and study of a set of values for wetlands, values related as "services" provided by these ecosystems (Tundisi \& Matsumura-Tundisi, 2008).

As there is a wide range of ecosystem services provided by wetlands, the removal of these environments undertakes the following processes: groundwater recharge, loss of biodiversity, changes in water quality (reduction in the concentration of phosphorus absorption in roots and biofilms of microorganisms denitrification due to the reduction of nitrates and nitrites to nitrous oxide and nitrogen gas, reducing the concentration of heavy metals) and erosion and sediment transport, among others (Tundisi \& Tundisi, 2010).

These systems receive, retain and recycle nutrients continuously brought from regions upstream and these nutrients support life in micro and macro scale, they allow inorganic transformations necessary organic material (directly or indirectly) to meet the nutritional demands ecosystem (Hammer, 1989).

Nutrient cycling in wetlands represent the summation of where and how the nutrients are found, and how they are transported from one compartment to another within the wetland itself, and what chemical changes that occur in it. The most important cycles that occur within a wetland are carbon, nitrogen, sulfur and phosphorus. The majority of the nutrients are found in the soil compartments followed by macrophyte (Valko, 2006).

In the Distrito Federal disorderly urban occupation led to a major environmental liabilities for hydrographic units. Among them, the hydrographic unit of Riacho Fundo, that had in recent years a very fast and disorganized urban development, lost large green areas that aided in the infiltration and retention of rainwater. Without native vegetation and riparian forests runoff was increased and consequently drains solids and nutrients to the unit delta.

Before water reach Lake Paranoá, its pass through a flooded area formed by a bank of weeds, small trees and lagoons, which for this study is called Riacho Fundo's wetland. Over time, due to a disorderly occupation of the basin, this wetland has expanded and continues to grow due to the load of solids and nutrients coming from upstream.

Being the Riacho Fundo's wetland an important area for the ecological balance and conserve the Lake Paranoá, that in the near future will be used as a source of water supply to Brasília, it is necessary to study the interactions of nutrients aiming to evaluate its ability to retain nutrients in order to control of eutrophication of Lake Paranoá.

The present study aimed to evaluate the capacity of Riacho Fundo's wetland in controlling eutrophicationof Lake Paranoá (Brasília, Brazil) by analyzing its ability to retain nitrogen and phosphorus. In addition, the multitemporal growth rate of wetland was measured to understand how it was formed and developement.

\subsection{Study area}

The watershed of the Riacho Fundo, Distrito Federal, drains areas belonging to the Paraná River Basin and empties into Lake Paranoá basin. This unit is composed of Riacho Fundo River, as the main river, which rises in the southwest region 
of the basin. Its main tributary of the right bank is Coqueiros stream and on left bank arise streams Vicente Pires and Guará. The area of interest of this study is located at the end of the Riacho Fundo River until the beginning of Lake Paranoá.

\section{Material and Methods}

\subsection{Sampling points}

Figure 1 illustrates the five points of water samples monitoring.

Point 1 is the bridge over the Riacho Fundo river that connects Brasília to the Juscelino Kubitschek
International Airport, considered the beginning of the wetland area and the cross section of the watershed of the creek Fund.

The second point is an intermediate point within the wetland, chosen in order to understand the behavior of nutrients throughout the study area. The vegetation of the right bank is composed of species of aquatic grass, and some small trees. On the left bank vegetation consists of a mosaic of Ludwigia octovalvis the top margin and the Polygonum ferrugineum.

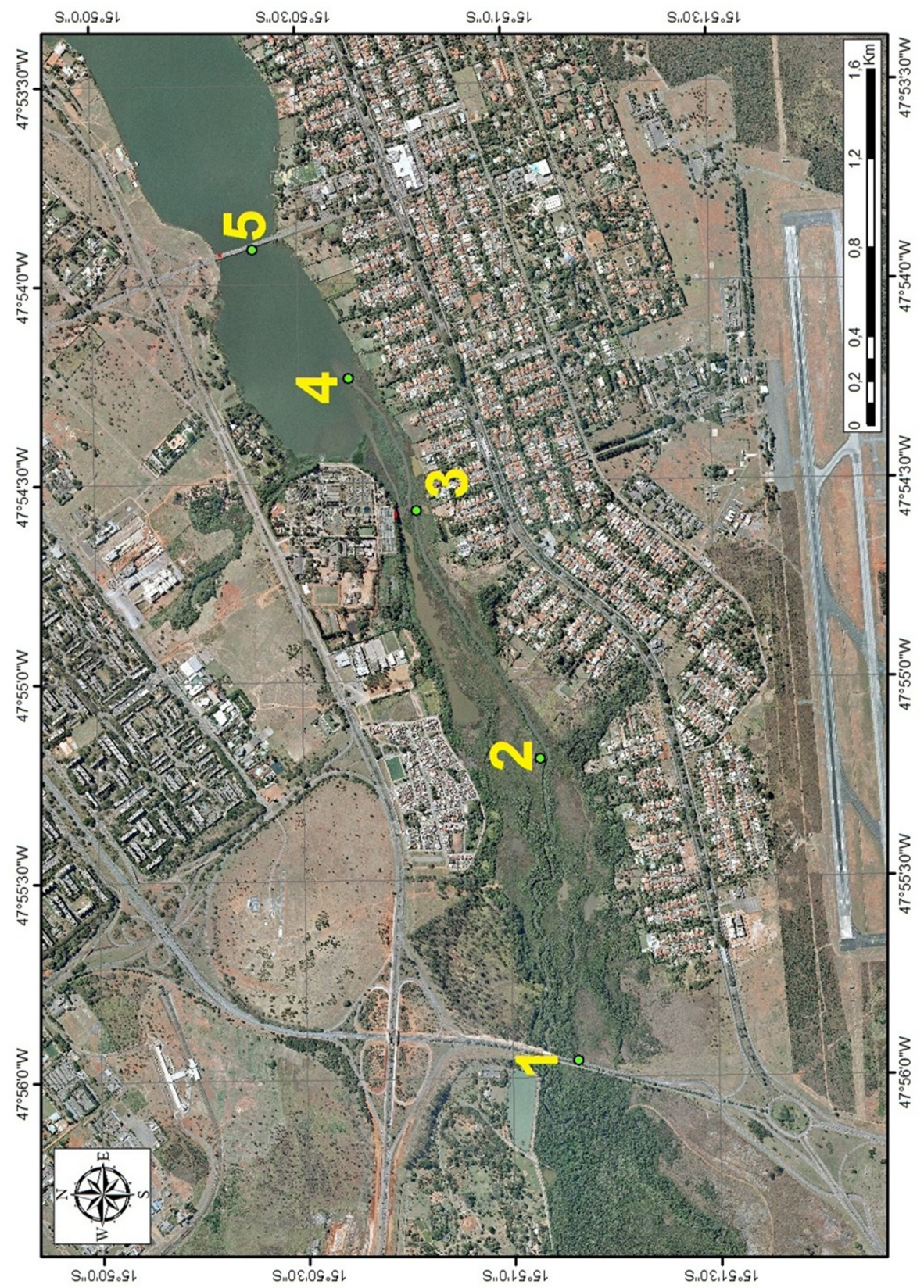

Figure 1. Samples points at Riacho Fundo's wetland. 
Point 3 is in a confluence that occurs in the two channels leading into the wetland. This point was chosen because it has a large lagoon connected with the output arm of the adjacent wetland can influence the outcome of the retention of nutrients.

The vegetation of the collection point 3 differs subtly in relation to the collection point 2 , however, the point is neighbor to the South Sewage Treatment Plant of Company of Environmental Sanitation of Distrito Federal. On its left bank has Eucalyptus trees planted in the area of South STP. On the right bank vegetation consists of grasses and aquatic Alternanthera philoxeroides by the entrance of the lagoon.

The fourth collection point is the point at the mouth of the wetland on Lake Paranoá and is considered as the main output of the wetland as it is in the main river terminating in the lake. The vegetation consists on both sides by Alternanthera philoxeroidespela, Eichhornia crassipes and Ludwigia octovalvis.

The fifth and final point was collected near the bridge President Medici who served as beacons to indicate whether there is an influence of the South Sewage Treatment Plant of Environmental Sanitation of the Federal District at the delta of the Riacho Fundo's wetland background.

\subsection{Parameters, sampling and analysis}

The parameters analyzed were total nitrogen, ammonia nitrogen, nitrite, nitrate, organic nitrogen, total nitrogen and total phosphorus in order to assess the nutrient load that can be retained in the wetland and no longer been deposited at the lake.

The samplings were made between November of 2011 to October 2012 every fifteen calendar days, comprising periods of rain and drought, totaling twenty-five samplings. Analyses were done in triplicate and performed at the Laboratory of Waters of the Catholic University of Brasília. The methods of sampling and analysis were in accordance with that specified by the Standard Methods for the Examination of Water and Wastewater (SMEWW) 21 st Edition of the American Public Health Association (APHA).

\subsection{Treatment of data}

In order to verify the similarity of the data from triplicate for each point the non-parametric test Kruskal-Wallis with a significance level of 5\% was used. The comparison between the sampling points was analyzed by the non-parametric teste of Wilcoxon-Mann-Whitney. The procedure adopted was to compare the point 1 with 2, 3, 4 and 5, then point 2 with 3, 4 and 5, and so on.

To evaluate the ability of Riacho Fundo's wetland to nutrients retention efficiency, the Equation 1 (Kadlec \& Knight, 1996) was performed using total nitrogen and phosphorus.

$\operatorname{Ef}(\%)=100 \times\left(\frac{[\mathrm{Ce}-\mathrm{Cs}]}{[\mathrm{Ce}]}\right)$

Where Ef is the efficiency percentage, Ce is the concentration of the parameter input and output $\mathrm{Cs}$ concentration. For this study $\mathrm{Ce}$ is point 1 of sampling and Cs are points 3 and 4, because there are two different kinds of aquatic environments, the river (4) and the lagoon (3). The calculation was performed separately considering the points 1 and 3 and 1 and 4 .

\subsection{Image processing}

The images used were obtained through site catalog images from the National Institute for Space Research - NISR, and are from the Landsat 1 and Landsat 5 TM from years 1973, 1985, 1995, 2005 and 2011. The images were processed in $\mathrm{ENVI}^{\circledR}$ software version 4.7 .

Images of each year were pre-processed and bands 1, 2, 3, 4, 5 and 7 grouped in a single file. The procedure started by the creation of sample polygons called ROI (Region of Interest) of the area of the wetland. Posterior the pixels have been exported to the n-Dimensional Visualizer module that allows visualization with multiple dimensions (one for each band image) and clouds or clusters of pixels that are grouped together due to spectral similarity.

This makes it possible to group the pixels pertaining to water, as have low radiance and are centered in the first bands of the visible light spectrum. These selected pixels allow the calculation of the area of water present in the scene making possible to determine how much water area was occupied by wetland vegetation of the years evaluated.

\section{Results and Discussion}

\subsection{Statistical tests}

Using the table of distribution $\chi^{2}$ to seventy-four degrees of freedom with $\alpha=0.05$, we obtain a $\chi^{2}$ tabulated of 51.7. No value of $\chi^{2}$ is bigger than the calculated found tabulated, therefore accept the null hypothesis that the data analyzed samples come from identical populations, thus concluding the validity of triplicates analyzed. 


\subsubsection{Comparison between the sampling points}

\subsubsection{Nitrogen}

The $t$ calculated number of total nitrogen during the precipitation as well as tabulated $t$ and the results for the period of drought. The distribution table of critical values were used of the test and $\alpha=0.05$ and GL $=\infty$, that obtains the value of tabulated $t$ of 1.6449. All values found in all parameters analyzed in the series of nitrogen in both seasons were higher than the tabulated $t$ thus reject the null hypothesis and conclude that the points are different, both in the dry season as in rainy.

The inputs of nitrogen within the Riacho Fundo's wetland may be from diffuse sources between points 1 and 4, due to the proximity of the neighborhood Vila Telebrasília and other natural or anthropogenic sources not measured in the present study as houses with illegal releases of sewage or agricultural additives upstream.

Wetlands are good retainers because they realize retaining nitrogen ammonification linked to the aerobic nitrification and denitrification in anaerobic zones, making any type of organic compound or inorganic nitrogen is being converted to nitrogen in the form of gas (Figure 2). Whereas points are statistically different from each other, it is found that the processes associated to the nitrogen cycle to occur as described in the literature.

Plants tend to accentuate the nitrogen removal in wetlands: directly through the assimilation of $\mathrm{NH}_{4}^{+}$and $\mathrm{NOx}$, and $\mathrm{O}_{2}$ for providing nitrification - denitrification (McBride \&Tanner, 2000). Another factor that shows that nitrogen is being retained by the wetland is the growth and maintenance of aquatic flora on site, because nitrogen is an essential nutrient for its growth.

The assimilation of nutrients by macrophytes relates to a range of biological processes that convert inorganic forms of nitrogen for organic compounds that are the basis for the cells and tissues of plants. Two commonly used forms of nitrogen as ammonia and nitrate are, however, ammonia, being energetically lower than the nitrate becomes the preferred source. In environments where nitrate is predominant, so it becomes the main source of inorganic nitrogen is likely to be assimilated (Kadlec \& Knight, 1996).

Total nitrogen behaved so as to decrease from point 1 to point 2 . Point 3 in the rain period had lower mean concentration at 4 , this due to the point 3 is a pond and have a higher hydraulic retention time, causing it to have a greater retention capacity at the time of rain. During the dry season the situation is reversed and section 3 there is a higher concentration of nutrients than in Section 4. This fact is due to the 3 point during the dry have a reduction in water volume resulting in the concentration of nutrients. Point 5 showed disparate behavior among nutrients of nitrogen studied series. During the period of drought and rain ammonia nitrogen, nitrite and total nitrogen remained with high average concentrations while the organic nitrogen and nitrate concentrations remained low average. It is noteworthy that a higher concentration of ammonia and nitrite may be coming from the emissary of South Sewage Treatment Plant of Environmental Sanitation Company of Distrito Federal, making the point 5 has strong influence of the effluent. The fact of finding low concentration of nitrate in Section 5 can be explained by preferential

\section{Total nitrogen}

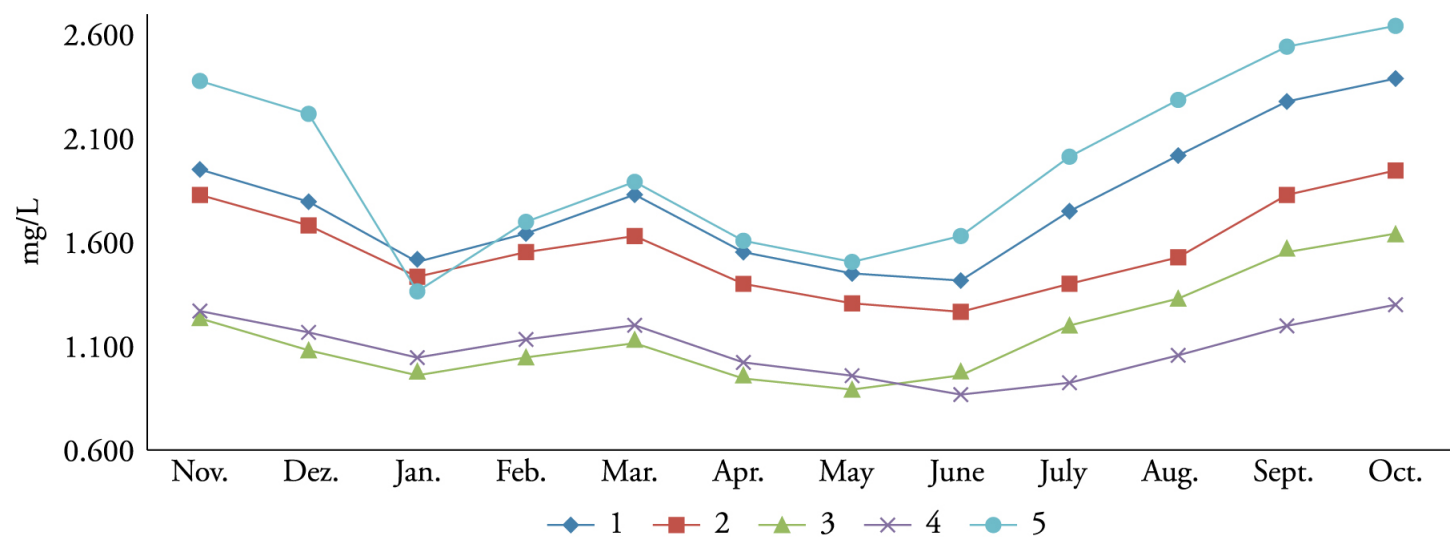

Figure 2. Total Nitrogen among the monitoring. 
absorption thus nitrogen by the phytoplankton community (Figure 2).

\subsubsection{Phosphorus}

Different from that found in the series of nitrogen by means of the Wilcoxon-Mann-Whitney test, some of the comparisons between the points of total phosphorus on rainy season showed the values of $t$ tabulated below the calculated $t$ and therefore accept the null hypothesis, allowing to conclude that the points are statistically similar. This occurred in the comparison between point 3 and 4; 1 and 5, and 2 and 5 . This fact occurs in order by the strong output that modifies the hydrodynamics (Table 1).

The other comparisons between points in the rainy season also rejected $\mathrm{H} 0$, i.e., the points are different. On the dry period, all comparisons rejected the null hypothesis.

The first comparison that occurred was similarity between point 3 and point 4 in total phosphorus. The statistical equality of points shows that they are similar in their concentrations of total phosphorus. This similarity between the points occurs because the process of natural wetland nutrient retention, which in the case of Sections 3 and 4 would already be at the end of the retention process.

Point 3 of sampling, that represents the exit of a lagoon within the study area, has a longer hydraulic retention and the soil of the region is the red latosoil, rich in iron oxide. The process of fixing the match with the $\mathrm{Fe}_{2}{ }^{+}$and $\mathrm{Fe}_{3}{ }^{+}$may have occurred more frequently than other processes involved in the cycle, causing its concentration decreased in relation to other points.

Phosphorus can co-precipitate with other minerals such as ferric hydroxide and calcium

Table 1. Comparison between points in total phosphorus parameter during the rainy season.

\begin{tabular}{lcc}
\hline Points compared & $\boldsymbol{t}$ calculated & $\boldsymbol{t}$ tabulated \\
\cline { 2 - 3 } & Total phosphorus & \\
\hline Point $1 \rightarrow$ Point 2 & 2.0263 & \\
Point $1 \rightarrow$ Point 3 & 6.3651 & \\
Point $1 \rightarrow$ Point 4 & 5.8284 & 1.6449 \\
Point $2 \rightarrow$ Point 3 & 4.9069 & \\
Point $2 \rightarrow$ Point 4 & 4.9069 & \\
Point $3 \rightarrow$ Point 4 & 1.2122 & \\
Point $1 \rightarrow$ Point 5 & 0.7515 & \\
Point $2 \rightarrow$ Point 5 & 1.1093 & \\
Point $3 \rightarrow$ Point 5 & 6.8080 & \\
Point $4 \rightarrow$ Point 5 & 6.2444 \\
\hline
\end{tabular}

Note: Highlighted in bold the t values calculated showed that fall below the tabulated. carbonate $\left(\mathrm{CaCO}_{3}\right)$. In soils of wetlands precipitation of phosphorus can occur in two forms in acidic and alkaline soils. In acidic soils phosphorus can be fixed by aluminum and iron, when they are available in alkaline soils and phosphorus may be fixed by calcium and magnesium, when available (Reddy \& D’Angelo, 1994). Inorganic phosphorus is used by organisms and converted into organic phosphorus by a process called immobilization (Vepraskas \& Faulkner, 2001).

Many studies have reported that phosphorus removal through assimilation by plants is low compared usual this nutrient loads entering wetland systems (Drizo et al., 1997; Neralla et al., 2000; Stottmeister et al., 2003).

Already in point 4 , that would be the end of the area and wetlands delta on Lake Paranoá also occurred the process of fixation of phosphorus by the $\mathrm{Fe} 2^{+}$and $\mathrm{Fe} 3^{+}$, due to the characteristics of the soil and the degree of sedimentation with little blade, causing there is a layer of anaerobic soil in which the fixing process occurs.

Another comparison that showed statistical similarity was between points 1 (end of the Riacho Fundo's basin) and 2 (wetland) and point 5 (Lake Paranoá) in total phosphorus for the period of rain (Figure 3). This similarity is due to the concentrations of phosphorus that reach the end of the basin (point 1) and enter the wetland (point 2) are statistically equal. The similarity between these points is justified by the fact that during the rainy season as the flow rate is greater than the dry season, there is a greater supply of nutrients in the wetland.

The concentration found in Lake Paranoá (point 5) is due to the influence of South Sewage Treatment Plant, the statistical analysis showed that points 1 and 2 are similar to point 5 in the rainy season. It can be stated that the nutrient load arising from the Riacho Fundo's watershed is equivalent to the South Sewage Treatment Plant discharge in Lake Paranoá after treatment of domestic and industrial sewage performed.

In general, the total phosphorus behaved so as to decrease from point 1 to point 2 in both monitored stations. Point 3 during the rainy season and drought had a mean concentration less than the point 4, but in the months of April and May the situation was reversed with section 4 having a lower average concentration that point 3 . This inversion effect can be decreasing the umbrella, and decreased load. Point 5 showed similar behaviors among the nutrients phosphorus studied series. In January the average concentration of total phosphorus 


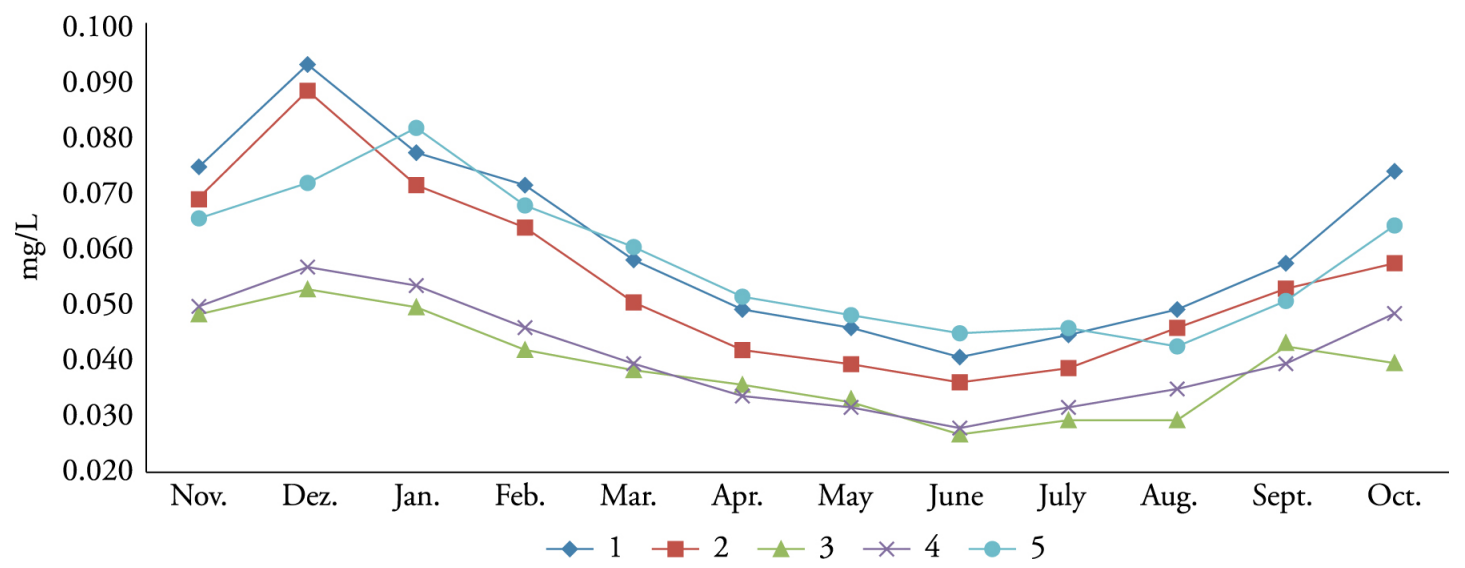

Figure 3. Total Phosphorous among the monitoring.

had a peak arising from the month of rain volume causing the load increase. Again the point shows the influence of the South Sewage Treatment Plant of CEBS with average concentrations of total phosphorus high.

\subsection{Calculation of efficiency of retention}

Tables 2 and 3 show the monthly average concentration of total nitrogen and phosphorus and their percentages of retention efficiency for the entire period investigated between point 1 and 4 to verify the efficiency of retention of the wetland in its main river.

It is noticed that there is an overall average retention efficiency of $38.23 \%$ for total nitrogen and $32.74 \%$ retention for total phosphorus throughout the collection period and analysis. The default retention efficiency of nitrogen deviation was 3.83\% and phosphorus $1.89 \%$.

Mule \& Nguta (2010) determined the retention efficiency of Kimondi wetland in terms of nitrogen and phosphorus. Results showed that retention efficiency of $90 \%$ and $95 \%$ for nitrogen during rainy and dry seasons respectively and mean retention efficiency of phosphorus of $80 \%$ and $93 \%$ during rainy and dry seasons respectively. Barten (1987) quote the Lake Clear (Minnesota) case that has become eutrophic due to ingress of water runoff rich in nutrients from the adjacent town of Waseca. In $1981,50 \%$ of the hydraulic load and $55 \%$ of the phosphorus load to the lake was diverted to a wet area of 21 ha. The wetland system reduced the annual phosphorus load by $34 \%$. In 1986 , construction was completed on a second system for filtering marsh of urban and agricultural runoff, leading to $20 \%$ reduction of the phosphorus load.
Table 2. Efficiency retention of total nitrogen in 1 and 4 .

\begin{tabular}{cccc}
\hline Months & $\begin{array}{c}\text { Point 1 } \\
\left(\mathbf{m g . l}^{-1}\right)\end{array}$ & $\begin{array}{c}\text { Point 4 } \\
\text { (mg. }^{-1} \text { ) }\end{array}$ & Ef\% \\
\hline November/2011 & 1.954 & 1.278 & 34.56 \\
December/2011 & 1.798 & 1.179 & 34.41 \\
January/2012 & 1.525 & 1.054 & 30.86 \\
February/2012 & 1.643 & 1.132 & 31.07 \\
March/2012 & 1.835 & 1.209 & 34.11 \\
April/2012 & 1.554 & 1.029 & 33.80 \\
May/2012 & 1.449 & 0.966 & 33.36 \\
June/2012 & 1.425 & 0.875 & 38.62 \\
July/2012 & 1.758 & 0.922 & 47.56 \\
August/2012 & 2.024 & 1.069 & 47.19 \\
September/2012 & 2.284 & 1.196 & 47.63 \\
October/2012 & 2.402 & 1.308 & 45.56 \\
\hline
\end{tabular}

Table 3. Efficiency retention of total phosphorus in points 1 and 4 .

\begin{tabular}{cccc}
\hline Months & $\begin{array}{c}\text { Point 1 } \\
\left(\mathbf{m g . I ^ { - 1 }}\right)\end{array}$ & $\begin{array}{c}\text { Point 4 } \\
\left(\mathbf{m g . I ^ { - 1 }}\right)\end{array}$ & Ef\% \\
\hline November/2011 & 0.0748 & 0.0500 & 33.20 \\
December/2011 & 0.0933 & 0.0569 & 39.00 \\
January/2012 & 0.0690 & 0.0533 & 31.25 \\
February/2012 & 0.0772 & 0.0456 & 36.46 \\
March/2012 & 0.0584 & 0.0396 & 32.14 \\
April/2012 & 0.0492 & 0.0337 & 31.40 \\
May/2012 & 0.0459 & 0.0316 & 31.09 \\
June/2012 & 0.0434 & 0.0280 & 31.46 \\
July/2012 & 0.0428 & 0.0314 & 30.30 \\
August/2012 & 0.0425 & 0.0352 & 28.65 \\
September/2012 & 0.0762 & 0.0398 & 30.89 \\
October/2012 & 0.0643 & 0.0488 & 33.84 \\
\hline
\end{tabular}

The total phosphorus concentration in the lake was reduced by $31 \%$ overall.

Studies conducted by García-García et al. (2009) reported the efficiency of nitrogen retention in natural Mediterranean wetlands that are affected 
by agricultural runoff to the retention of nitrate- $\mathrm{N}$ reaching high as $72.3 \%$. Sousa (2004) found an efficiency of nutrient removal in satisfactory $60 \%$ nitrogen and $80 \%$ of phosphorus of a constructed wetland wastewater treatment.

Tables 4 and 5 show the monthly average concentration of total nitrogen and phosphorus and their percentages of retention efficiency for the entire period investigated between point 1 and 3 to verify the efficiency of retention of the wetland lagoon. It is found that there is a general average retention efficiency of $35.09 \%$ for total nitrogen and $35.43 \%$ for total phosphorus retention during the period of sampling and analysis. The default retention efficiency of nitrogen deviation was $3.17 \%$ and $6.48 \%$ phosphorus.

\subsection{Image analyses}

Table 6 brings the year of the image and the estimated area of water in the wetland area. You can see that from 1973 to 1985 there was a loss of water area estimated $0.3626 \mathrm{~km}^{2}$ or $42.19 \%$ of the initial area.

Comparatively analyzing the processed images of the years 1985 and 1995 there is a loss of water area estimated $0.0450 \mathrm{~km}^{2}$ or $17.01 \%$, and when comparing the picture of 1995 with the initial image of 1973, estimated a loss of water area of $0.3501 \mathrm{~km}^{2}$ or $59.24 \%$ of the initial area. From 1995 to 2005 there was no loss of water area, unlike previous years, there was a gain. This fact is evidenced by the estimated water area has passed from $0.2196 \mathrm{~km}^{2}$ in 1995 to $0.2250 \mathrm{~km}^{2}$ in 2005 (Figure 4). This fact was due to the emergence of the lagoon, which in this study was considered as a point of confluence of the point 3 with the main branch, from 1995 to 2005 . This represented an increase of $0.0054 \mathrm{~km}^{2}$ or $2.46 \%$ area of 1995 to 2005 .
Table 4. Efficiency retention of total nitrogen in 1 and 3.

\begin{tabular}{cccc}
\hline Months & $\begin{array}{c}\text { Point 1 } \\
\left(\mathbf{m g . l}^{-1}\right)\end{array}$ & $\begin{array}{c}\text { Point 3 } \\
\text { (mg. }^{-1} \text { ) }\end{array}$ & Ef\% \\
\hline November/2011 & 1.954 & 1.245 & 36.27 \\
December/2011 & 1.798 & 1.084 & 39.71 \\
January/2012 & 1.525 & 0.985 & 35.37 \\
February/2012 & 1.643 & 1.047 & 36.26 \\
March/2012 & 1.835 & 1.130 & 38.42 \\
April/2012 & 1.554 & 0.962 & 38.14 \\
May/2012 & 1.449 & 0.902 & 37.73 \\
June/2012 & 1.425 & 0.979 & 31.30 \\
July/2012 & 1.758 & 1.207 & 31.32 \\
August/2012 & 2.024 & 1.335 & 34.03 \\
September/2012 & 2.284 & 1.573 & 31.13 \\
October/2012 & 2.402 & 1.649 & 31.37 \\
\hline
\end{tabular}

Table 5. Efficiency retention of total phosphorus in points 1 and 3 .

\begin{tabular}{llll}
\hline \multicolumn{1}{c}{ Months } & $\begin{array}{c}\text { Point 1 } \\
\text { (mg. } \mathbf{I}^{-1} \text { ) }\end{array}$ & $\begin{array}{c}\text { Point 3 } \\
\text { (mg. } \text { I }^{-1} \text { ) }\end{array}$ & Ef\% \\
\hline November/2011 & 0.0748 & 0.0485 & 35.17 \\
December/2011 & 0.0933 & 0.0528 & 43.36 \\
January/2012 & 0.0690 & 0.0496 & 36.02 \\
February/2012 & 0.0772 & 0.0423 & 41.03 \\
March/2012 & 0.0584 & 0.0381 & 34.82 \\
April/2012 & 0.0492 & 0.0358 & 27.18 \\
May/2012 & 0.0459 & 0.0336 & 26.86 \\
June/2012 & 0,0434 & 0.0269 & 34.19 \\
July/2012 & 0.0428 & 0.0297 & 34.18 \\
August/2012 & 0.0425 & 0.0292 & 40.82 \\
September/2012 & 0.0762 & 0.0434 & 24.68 \\
October/2012 & 0.0643 & 0.0392 & 46.86 \\
\hline
\end{tabular}

Table 6. Years of images and areas.

\begin{tabular}{cc}
\hline Year image & Area in square kilometers \\
\hline 1973 & 0.6272 \\
1985 & 0.2646 \\
1995 & 0.2196 \\
2005 & 0.2250 \\
2011 & 0.0999 \\
\hline
\end{tabular}

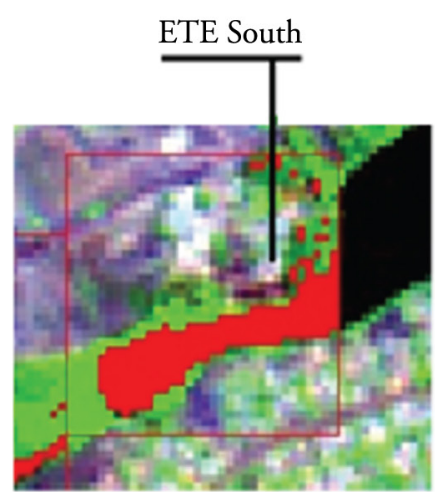

1985

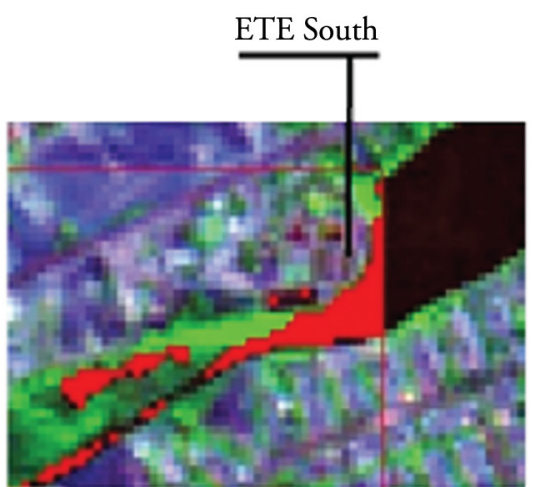

1995

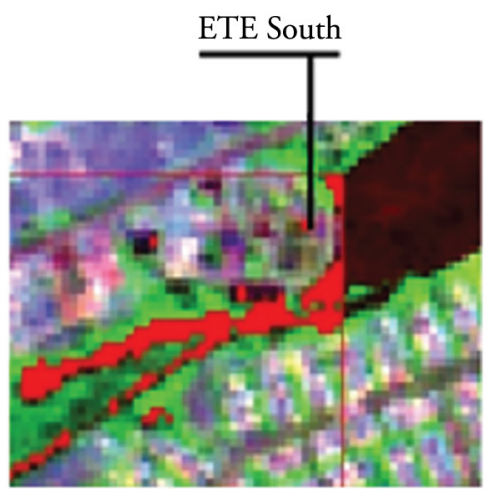

2005

Figure 4. Growth between years 1985, 1995 and 2005. The red spots are water area and the green spot vegetation. 
When comparing 2005 to early 1973 still sense a decrease in the area of $0.3587 \mathrm{~km}^{2}$ or $59.78 \%$ of the initial water area. In 2011 the water area was estimated at $0.0999 \mathrm{~km}^{2}$. For the year 2005 the area had a loss of area of $0.1251 \mathrm{~km}^{2}$ water representing $55.60 \%$ of the area in 2005 . For the year 1973 the loss of water area was $0.5273 \mathrm{~km}^{2}$ or $84.07 \%$ of the initial area of water in 38 years studied. The growing trough the years can be visualized on Figure 5 .
This loss of water area of Lake Paranoá and subsequent formation Riacho Fundo's wetlands specified depending on the use and occupation of the cluttered background of Riacho Fundo basin. Green and riparian areas were devoid of plantings for use and urbanization resulting in increased runoff along with solids and nutrients that have been contributed at the mouth of the basin resulting in the Riacho Fundo wetland.

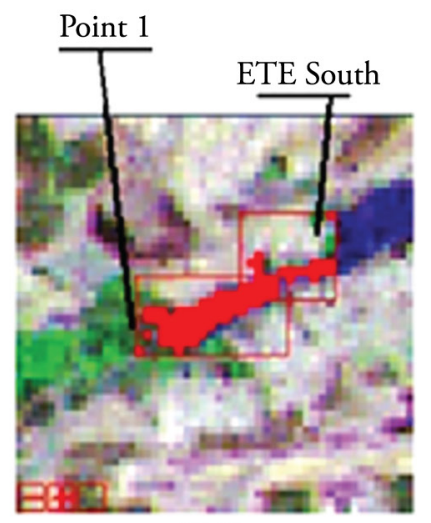

1973

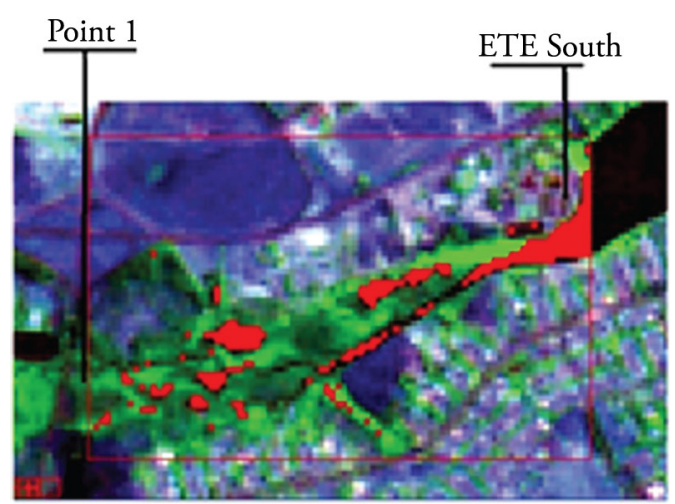

1995

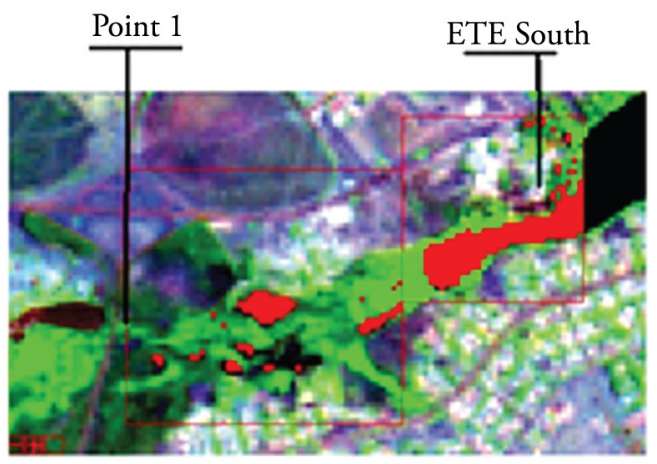

1985

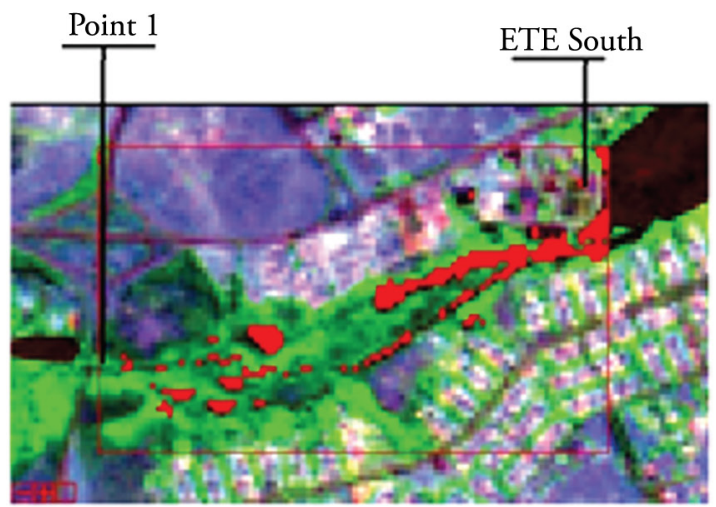

2005

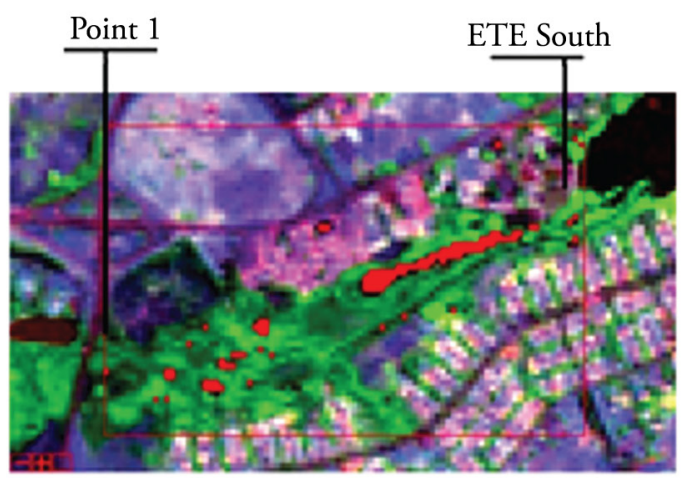

2011

Figure 5. Comparison between the years 1973, 1985, 1995, 2005 and 2011 of wetland growth. The red spots are water area and the green spot vegetation. 


\section{Conclusion}

Nitrogen and phosphorus as macronutrients and limiting factors for the development of plants were incorporated into the soil, roots, plants and microorganisms by the aforementioned processes in their cycles being left dock into Lake Paranoá. This incorporation of nutrients along with the protection of plants and animals of Lake Paranoá are considered wetland ecological services provided by the Riacho Fundo's wetland to Lake Paranoá.

The statistical analysis of the parameters of the series of total nitrogen and total phosphorus showed that the Riacho Fundo's wetland is conducting a process of assimilation of the same so as to retain the general average of $36.66 \%$ nitrogen and $33.96 \%$ of total phosphorus. In case of absence of wetland, total nitrogen and total phosphorus coming from the background of the Riacho Fundo River will deposit into Lake Paranoá and may cause excessive concentration of nutrients in the lake, triggering eutrophication.

Satellite images contribute to identify and show how the Riacho Fundo's wetland grew trough the years. This tool could be very useful to wetlands monitoring and management in a way to provide spatial information to measure wetland area.

Knowing that in the near future Paranoá Lake will be used as a public water supply it is necessary to preserve the quality of water and areas that assist in this process. Thus the wetland is playing an ecological service water treatment and preservation of aquatic and terrestrial life of the lake and its importance should be considered in the Lake Paranoá management.

\section{Acknowledgements}

Special thanks to Waters Laboratory of the Catholic University of Brasília for their support in the implementation of laboratory tests and the Institute of Geosciences of the University of Brasilia. Finally, the authors thank Professor Cynthia Ann Bell-Santos of New Mexico State University, for review and translation to English.

\section{References}

BARTEN, J.M. Stormwater Runoff treatment in a Wetland filter: effects on the water quality of Clar Lake. Lake and Reservoir Management, 1987, 3(1), 297-305. http://dx.doi.org/10.1080/07438148709354785.

DRIZO, A., FROST, C.A., SMITH, K.A. and GRACE, J. Phosphate and ammonium removal by constructed wetlands with horizontal subsurface flow, using shale as a substrate. Water Science and Technology, 1997,
35(5), 95-102. http://dx.doi.org/10.1016/S02731223(97)00057-7.

GARCÍA-GARCÍA, V., GÓMEZ, R., VIDALABARCA, M.R. and SUÁREZ, M.L. Nitrogen retention in natural Mediterranean wetland-streams affected by agricultural runoff. Hydrology and Earth System Sciences, 2009, 13(12), 2359-2371. http:// dx.doi.org/10.5194/hess-13-2359-2009.

HAMMER, D.A. Constructed wetlands for wastewater treatment: municipal, industrial and agricultural. Chelsea: Lewis Publications, 1989, 350 p.

KADLEC, R.H. and KNIGHT, R.L. Treatment Wetlands. Boca Raton: Lewis Publishing, 1996.

MCBRIDE, G.B. and TANNER, C.C. Modelling biofilm nitrogen transformations in constructed wetland mesocosms with fluctuating water levels. Ecological Engineering, 2000, 14, 93-106.

MULE, S.M. and NGUTA, C.M. Determination of retention efficiency of Kimondi Wetland in North Nandi district in Kenya. In Handbook of research on hydroinformatics: technologies, theories and applications. Hershey: IGI Global, 2010, pp. 419-430. http://dx.doi.org/10.4018/978-1-61520907-1.ch021.

NERALLA, S., WEAVER, R.W., LESIKAR, B.J. and PERSYN, R.A. Improvement of domestic wastewater quality by subsurface flow constructed wetlands. Bioresource Technology, 2000, 75(1), 19-25. http:// dx.doi.org/10.1016/S0960-8524(00)00039-0.

REDDY, K.R. and D'ANGELO, E.M. Soil processes regulating water quality in wetlands. In: W.J. Mitsch, ed. Global wetland: old world and new. Amsterdam: Elsevier BV, 1994, pp. 309-324.

SOUSA, J.T. Utilização de wetland construído no pós-tratamento de esgotos domésticos prétratados em reator UASB. Engenharia Sanitaria e Ambiental [online], 2004, 9(4), 285-290. [viewed 19 Abr. 2013]. Available from: http://www.scielo. br/scielo.php?script=sci_arttext\&pid=S1413$41522004000400004 \& \operatorname{lng}=$ en $\& n r m=$ iso.

STOTTMEISTER, U., WIESSNER, A., KUSCHK, P., KAPPELMEYER, U., KÄSTNER, M., BEDERSKI, O., MÜLLER, R.A. and MOORMANN, H. Effects of plants and microorganisms in constructed wetlands for wastewater treatment. Biotechnology Advances, 2003, 22(1-2), 93-117. http://dx.doi.org/10.1016/j. biotechadv.2003.08.010. PMid:14623046.

TUNDISI, J.G. and MATSUMURA-TUNDISI, T. Limnology. London: Office of Texts, 2008, 632 p.

TUNDISI, J.G., and TUNDISI, T.M. Potential impacts of changes in the Forest Code on water resources. Biota Neotropica, 2010, 10(4), 67-75.

VALKO, A.G. The biology of Freshwater Wetlands: biology of habitats. Oxford: Oxford University Press, 2006, $173 \mathrm{p}$. 
VEPRASKAS, M.J. and FAULKNER, S.P. Redox chemistry of hydric soils. In J.L. Richardson and M.J. Vepraskas, eds. Wetland soils. Boca Raton: Lewis Publishers, 2001, pp. 85-105.

WEBER, C. and PUISSANT, A. Urbanization pressureand modeling of urban growth: example of the Tunismetropolitan area. Remote Sensing of Environment, 2003, 86(3), 341-352. http://dx.doi. org/10.1016/S0034-4257(03)00077-4.

WELSCH, D.J., SMART, D.L., BOYER, J.N., MINKIN, P., SMITH, H.C. and MCCANDLESS, T.L. FForested Wetlands: functions, benefits and the use of best management practcies. Radnor: U.S. Department of Agriculture, 1995, 63 p.

XU, K., KONG, C.F., WU, C.L., LIU, G., DENG, H.B. and ZHANG, Y. Dynamic changes in Tangxunhu wetlandover a period of rapid development (19532005) in Wuhan, China. Wetlands, 2009, 29(4), 1255-1261. http://dx.doi.org/10.1672/08-238.1.

Received: 14 January 2014

Accepted: 13 August 2015 